\title{
PENGARUH KOMUNIKASI GURU DAN BUDAYA SEKOLAH TERHADAP MOTIVASI BELAJAR SISWA SMP NURUL ISLAM NGEMPLAK BOYOLALI
}

\author{
Muhtadin \\ Email: muhtadin@dsn.moestopo.ac.id \\ Fakultas Ilmu Komunikasi Univ. Prof. Dr. Moestopo (Beragama)
}

\begin{abstract}
ABSTRAK
Penelitian ini membahas tentang komunikasi guru dan budaya sekolah apakah dapat mempengaruhi baik secara parsial maupun simultan terhadap motivasi belajar siswa SMP Nurul Islam Ngemplak Boyolali. Penelitian ini bertujuan untuk menguji secara empiris pengaruh komunikasi guru terhadap motivasi belajar siswa, pengaruh budaya sekolah terhadap motivasi belajar siswa, dan pengaruh komunikasi guru dan budaya sekolah secara simultan terhadap motivasi belajar siswa SMP Nurul Islam Ngemplak Boyolali. Populasi dalam penelitian ini adalah siswa kelas VIII dan IX SMP Nurul Islam Ngemplak Boyolali yang berjumlah 138 siswa, sedangkan untuk pengambilan sampel menggunakan random sampling dan ukuran sampel menggunakan rumus Isac dan Michael dengan jumlah sampel sebanyak 100 siswa. Berdasarkan hasil pengolahan data, pengujian hipotesis, maupun analisis hasil penelitian, maka dapat disimpulkan secara umum bahwa hasil penelitian ini sejalan dengan teori motivasi berprestasi yang dikemukakan oleh David Mc Clelland. Sedangkan kesimpulan secara khusus adalah ada pengaruh positif dan signifikan antara komunikasi guru terhadap motivasi belajar siswa, pengaruh positif dan signifikan antara budaya sekolah terhadap motivasi belajar siswa, dan pengaruh positif dan signifikan antara komunikasi guru dan budaya sekolah secara simultan terhadap motivasi belajar siswa.
\end{abstract}

Kata kunci: Kumunikasi guru; Budaya Sekolah; Motivasi Belajar

\section{ABSTRACT}

This study discusses the communication of teachers and school culture whether it can affect both partially and simultaneously on the motivation of students studying at Nurul Islam Ngemplak Boyolali Middle School. This study aims to empirically examine the effect of teacher communication on student learning motivation, the influence of school culture on student learning motivation, and the effect of teacher communication and school culture simultaneously on student motivation in teaching Nurul Islam Ngemplak Boyolali Middle School. The population in this study were students of class VIII and IX SMP Nurul Islam Ngemplak Boyolali, amounting to 138 students, while for sampling using random sampling and sample size using the Isac and Michael formula with a total sample of 100 students. Based on the results of data processing, hypothesis testing, and analysis of research results, it can be concluded in general that the results of this study are in line with the achievement motivation theory proposed by David Mc Clelland. While the conclusion specifically is there is a positive and significant effect between teacher communication on student motivation, positive and significant influence between school culture on student motivation, and positive and significant influence between teacher communication and school culture simultaneously on student motivation.

Keywords: Teacher communication; School Culture; Learning Motivation 


\section{Pendahuluan}

Undang-Undang Dasar Negara (UUD)

Republik Indonesia Tahun 1945 yangmenyatakan bahwa setiap warga negara berhak mendapatkan pendidikan dan pengajaran yang layak tanpa memandang suku, agama, ras dan golongan. Selain itu, salah satu tujuan dari Negara Republik Indonesia adalah mencerdaskan kehidupan bangsa. Dalam kaitannya dengan dunia pendidikan, proses pembelajaran akan efektif, jika komunikasi dan interaksi antara guru dengan siswa terjadi secara intensif. Guru dapat merancang model-model pembelajaran sehingga siswa dapat belajar secara optimal.

Guru mempunyai kewajiban yang sangat penting di dalam proses belajar mengajar di antaranya adalah menyampaikan materi pelajaran kepada siswa melalui interaksi komunikasi. Guru dikatakan berhasil dalam menyampaikan materi pelajaran apabila dapat berjalan lancar dalam berinteraksi dengan siswanya begitu pula sebaliknya bahwa guru tidak akan berhasil apabila guru tidak bisa berinteraksi dengan siswa secara baik.

Dalam kehidupan sehari-hari komunikasi merupakan bagian dasar dari kehidupan manusia itu sendiri, karena manusia sebagai makhluk sosial selalu melakukan komunikasi di setiap aktivitas, dimanapun, dan kapanpun waktunya. Komunikasi sangat urgen dalam kehidupan bermasyarakat. Hal ini bukan dikarenakan kemajuan teknologi melainkan hasrat manusia yang selalu ingin bersosialisasi dan berinteraksi dengan makhluk sesamanya.

Proses pembelajaran selalu melibatkan tiga komponen yang terdiri dari guru, siswa dan pesan. Guru berperan sebagai komunikator yang berfungsi untuk menyampaikan informasi atau pengajaran kepada siswa. Komponen yang kedua adalah siswa merupakan salah satu faktor dari proses komunikasi karena itu unsur siswa tidak boleh diabaikan, sebab berhasil tidaknya suatu proses sangat ditentukan oleh siswa.

Komunikasi merupakan usaha penyampaian pesan antar sesama manusia, komunikasi adalah ilmu yang mempelajari usaha penyampaian pesan antar manusia (Soyomukti, 2010:56). Komunikasi bertujuan untuk menyampaikan informasi, mendidik dan untuk mempengaruhi tingkah laku si penerima informasi yang dinyatakan dalam tindakan-tindakan tertentu sebagai respons terhadap informasi yang diterimanya.yaitu perubahan sikap, perubahan pendapat (opinion change), perubahan perilaku dan perubahan social (social change). (Effendy, 2006).

Islam mengajarkan kepada manusia untuk berkomunikasi yang bertujuan untuk saling kenal mengenal, bekerja sama, berbuat kebaikan, baik untuk kemasyarakatan, keagamaan maupun untuk individual. Hal ini sbagaimana firman Allah SWT dalam surat al-Hujurat ayat 13 :

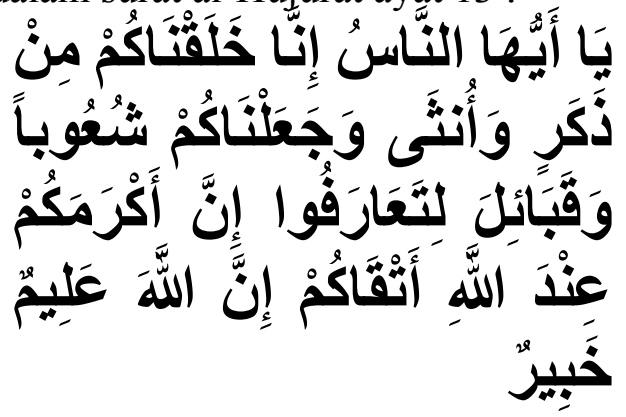

"Hai manusia, sesungguhnya kami menciptakan kamu dari seorang laki-laki dan seorang perempuan dan menjadikan kamu berbangsa-bangsa dan bersuku-suku supayakamu saling kenal mengenal. Sesungguhnya orang yang paling mulia di sisi Allah ialah orang yang paling bertaqwa diantara kamu sesungguhnya Allah Maha Mengetahui lagi Maha Mengenal" (Q.S. AlHujarat: 13)

Proses belajar mengajar merupakan suatu proses terjadinya interaksi antara guru dan siswa yaitu kegiatan belajar bagi siswa dan kegiatan mengajar bagi guru. Belajar adalah proses perubahan tingkah laku pada diri seorang siswa berkat pengalaman dan pelatihan . Pengalaman dan pelatihan itu terjadi melalui interaksi antara individu dan lingkungannya. (Hamalik, 2009:16) 
Untuk mencapai interaksi belajar mengajar yang efektif, sudah barang tentu adanya komunikasi yang jelas antara guru (pengajar) dengan siswa (pelajar) sehingga terpadunya dua kegiatan yakni kegiatan mengajar (usaha guru) dengan kegiatan belajar (tugas siswa) yang berdaya guna dalam mencapai pengajaran. Sering kita jumpai kegagalan pengajaran disebabkan lemahnya sistem komunikasi, untuk itulah guru perlu mengembangkan pola komunikasi yang efektif dalam proses belajar mengajar. (Muhaimin, 2010). Ada tiga pola komunikasi yang dapat di gunakan untuk mengembangkan interaksi dinamis antara guru dengan siswa yaitu: a) Komunikasi sebagai aksi atau komunikasi satu arah. Dalam komunikasi ini guru berperan sebagai pemberi aksi dan siswa sebagai penerima aksi misalnya guru menerangkan pelajaran dengan menggunakan metode ceramah, sementara siswa mendengarkan keterangan dari guru tersebut; b) Komunikasi sebagai interaksi atau komunikasi dua arah. Pada Komunikasi ini guru dan siswa dapat berperan sama, yakni pemberi aksi dan penerima aksi sehingga keduanya dapat saling memberi dan menerima. Misalnya setelah guru memberi penjelasan pelajaran kepada siswanya, kemudian guru memberi pertanyaan kepada siswanya dan siswa menjawab pertanyaan tersebut; c) Komunikasi banyak arah atau komunikasi sebagai transaksi. Yakni komunikasi yang tidak hanya melibatkan interaksi dinamis antar guru dengan siswa tetapi juga melibatkan interaksi dinamis antara siswa yang satu dengan siswa yang lainnya. Misalnya guru mengadakan diskusi dalam kelas. (Liliweri, 2013). Dengan adanya tiga pola komunikasi yang jelas dari komunikator kepada komunikan diharapkan dapat memperlancar proses kegiatan belajar mengajar secara efektif dan efisien.

Selain komunikasi, budaya sekolah juga mempunyai peranan yang sangat penting bagi kemajuan sekolah pada umumnya, dan motivasi belajar siswa pada khususnya. Sekolah memiliki struktur sosial di dalamnya terdapat berbagai tingkatan dan jabatan seperti kepala sekolah, wakil kepala sekolah, guru dan sebagainya. Mereka memilki tugas dan kewajiban sesuai dengan kedudukannya dan mereka saling berinteraksi tolongmenolong bersatu padu untuk mewujudkan kesatuan dalam memajukan sekolah sehingga sekolah tersebut bisa disebut sebuah organisasi. Sekolah termasuk organisasi formal dan memiliki budaya. Budaya sekolah bisa dibentuk ketika anggota-anggotanya saling berinteraksi dan budaya sekolah juga bisa dipengaruhi oleh faktor-faktor internal dan eksternal sekolah maka setiap sekolah memiliki budaya yang berbeda-beda (Suriansyah, 2014).

Budaya sekolah umumnya mencakup ritual, harapan, hubungan, demografi, kegiatan kurikuler, kegiatan ekstrakurikuler, kebijakan maupun interaksi sosial di sekolah. Interaksi internal kelompok dan antar kelompok terikat oleh berbagai aturan, norma, moral serta etika yang berlaku di suatu sekolah. Ansar \& Masaong menyatakan bahwa budaya sekolah memiliki empat karakteristik yaitu: a) budaya sekolah yang bersifat khusus (distinctive) karena masing-masing sekolah memiliki sejarah, pola komunikasi, sistem dan prosedur, pernyataan visi dan misi; b) budaya sekolah pada hakikatnya stabil dan biasanya berubah, dimana budaya sekolah akan berubah bila ada ancaman "krisis" dari sekolah yang lain; c) budaya sekolah biasanya memiliki sejarah yang bersifat implisit dan tidak eksplisit; d) budaya sekolah tampak sebagai perwakilan simbol yang melandasi keyakinan dan nilai-nilai sekolah tersebut. (Ansar dan Masaong, 2005:186).

Dari karakteristik ini, dapat dikatakan bahwa kejadian-kejadian internal dan eksternal yang terjadi di sekolah bisa mengubah budaya sekolah misalnya: kondisi dasar, teknologi baru, perubahan kebijakan, dan faktor lain. Karakteristik budaya sekolah yang lain, seperti yang dikemukakan oleh Nurkholis adalah : a) 
budaya sekolah akan lebih mudah dipahami ketika elemen-elemennya terintegerasi dan konsisten antara yang satu dengan yang lain; b) sebagian besar warga sekolah harus menerima nilai-nilai budaya sekolah; c) sebagian besar budaya sekolah berkembang dari kepala sekolah yang memiliki pengaruh yang besar terhadap gurunya; d) budaya sekolah bersifat menyeluruh pada semua sistem; e) budaya sekolah memiliki kekuatan yang bervariasi, yaitu kuat atau lemah tergantung pada pengaruhnya terhadap perilaku warga sekolah. (Nurkholis, 2006:46).

Dengan memperhatikan berbagai macam karakteristik budaya sekolah yang telah dikemukakan di atas, maka dapat disimpulkan bahwa budaya sekolah dipengaruhi oleh banyak faktor antara lain semangat guru dalam mengajar; guru yang berpotensial; kedisiplinan sekolah; proses pembelajaran yang efektif; peraturan yang tegas; sikap guru terhadap siswa yang terbuka dan; kepemimpinan kepala sekolah yang demokratis dan sebagainya.

Dalam proses belajar mengajar, supaya dapat menghasilkan belajar yang memuaskan maka diperlukan suatu motivasi dari siswa, motivasi siswa sangat berpotensi dalam mendukung kegiatan belajar mengajar. Motivasi belajar siswa bisa dipengaruhi oleh dua faktor yaitu faktor internl dan faktor eksternal. Komunikasi guru dengan siswa mempunyai pengaruh yang besar terhadap motivasi belajar siswa, karena banyak kegagalan dalam proses belajar mengajar disebabkan jarangnya komunikasi guru dengan siswa sehingga guru tidak bisa menumbuhkan motivasi belajar siswa. Jadi motivasi belajar siswa itu sangat dipengaruhi oleh komuniksi guru terhadap siswa (Sudrajat, 2011)

Motivasi dalam kegiatan belajar merupakan keseluruhan daya penggerak dalam diri peserta didik yang menimbulkan kegiatan belajar, yang menjamin kelangsungan dari kegiatan belajar dan yang memberikan arah pada kegiatan belajar, sehingga tujuan yang dikehendaki oleh subyek belajar itu dapat tercapai. Dikatakan keseluruhan, karena pada umumnya ada beberapa motif yang bersama-sama menggerakkan peserta didik untuk belajar. Motivasi belajar merupakan faktor psikis yang bersifat non-intelektual. Peranan motivasi yang khas adalah dalam menumbuhkan gairah, merasa senang dan semangat untuk belajar. Peserta didik yang memiliki motivasi kuat, akan mempunyai banyak energi untuk melakukan kegiatan belajar (Sardiman, 2001: 73).

Motivasi belajar siswa dapat berubah sewaktu-waktu, terkadang tinggi dan terkadang rendah. Menurut Darsono (1984: 64-67), siswa yang memiliki motivasi belajar tinggi atau rendah diindikasikan dengan hal-hal berikut: citacita atau aspirasi, kemampuan belajar, kondisi peserta didik, kondisi lingkungan, unsur-unsur dinamasi dalam belajar dan upaya guru membelajarkan peserta didik. Bila upaya tersebut dilkasanakan dengan sunggung-sungung berorientasi pada kepentingan peserta didik maka diaharapkan akan dapat meningkatkan motivasi belajar perserta didik.

Penelitian terdahulu yang relevan dengan penelitian ini yang pertama oleh Evi Rahmawati (2014) dengan judul "Pengaruh Lingkungan Sekolah Terhadap Motivasi Belajar Siswa di SMP Muhammadiyah 22 Pamulang", terdapat hubungan positif antara lingkungan sekolah terhadap motivasi belajar. Hal ini ditunjukkan dengan ro sebesar 0,480 sedangkan $\mathrm{rt}$ sebesar 0,325 dan 0,418. Dengan demikian ro lebih besar daripada $\mathrm{rt}(0,480>0,325<$ 0,418 ) baik dalam taraf signifikansi 5\% maupun 1\%. Maka Ha diterima dan Ho ditolak. Yang kedua penelitian yang dilakukan oleh Rizki Alfiandi (2014), yang berjudul "Korelasi Antara Profesionalisme Guru PAI dengan Prestasi Belajar Siswa di SMP Dua Mei Ciputat", dalam penelitian ini menunjukkan bahwa korelasi antara profesionalisme guru PAI terhadap prestasi belajar siswa mempunyai korelasi yang positif yang cukup dan signifikan yaitu 0,40 , pada taraf signifikan $5 \%$ diketahui 
bahwa $0,40>0,320$ ( $\mathrm{r}$ hitung lebih besar daripada $r$ tabel). dan yang ketiga dilakukan oleh Dewi Nurwulan (2015), yang berjudul "Pengaruh Budaya Sekolah terhadap Prestasi Belajar Siswa Pada Mata Pelajaran PAI", hasil dari penelitian ini adalah budaya sekolah berpengaruh dengan prestasi belajar PAI dengan tingkat hubungan yang lemah.

Berdasarkan penjelasan di atas, penelitian ini bertujuan untuk mengetahui besarnya pengaruh komunikasi guru (X1) terhadap motivasi belajar siswa (Y) SMP Nurul Islam Ngemplak Boyolali, ntuk mengetahui besarnya pengaruh budaya sekolah (X2) terhadap motivasi belajar siswa (Y) SMP Nurul Islam Ngemplak Boyolali, untuk mengetahui besarnya pengaruh secara simultan variabel komunikasi guru (X1) dan variabel budaya sekolah (X2) terhadap motivasi belajar siswa (Y) SMP Nurul Islam Ngemplak Boyolal, dan ntuk mengetahui variabel yang paling dominan mempengaruhi motivasi belajar siswa (Y) SMP Nurul Islam Ngemplak Boyolali.

\section{Metode Penelitian}

Penelitian dapat tercapai sesuai dengan rencana yang telah ditetapkan dan memperoleh hasil yang baik apabila dalam penelitian menggunakan metode yang tepat. Penelitian ini adalah bersifat kuantitatif dengan menggunakan metode survei dengan pendekatan korelasional. Hal ini digunakan untuk mendapatkan data setiap variabel dengan alat pengumpulan data berupa angket (kuesoner), test dan wawancara tersetruktur. Penelitian termasuk jenis penelitian terapan yaitu penelitian yang dilakukan dengan tujuan menerapkan, menguji, mengevaluasi kemampuan suatu teori yang dipergunakan untuk memecahkan masalah-masalah praktis (Suriasumantri, Jujun S,2003:110).

Penelitian ini ada dua variabel bebas, yaitu pertama komunikasi guru dan budaya sekolah. kedua satu variabel terkait yaitu motivasi belajar siswa. Metode ini dipilih sesuai dengan tujuan peneliti yaitu ingin mengetahui pengaruh variabel komunikasi guru terhadap motivasi belajar siswa, pengaruh variabel budaya sekolah terhadap motivasi belajar siswa, dan pengaruh variabel komunikasi guru dan budaya sekolah terhadap motivasi belajar siswa.

Populasi adalah wilayah generalisasi yang terdiri atas objek/subjek penelitian yang memiliki kualitas dan karakteristik tertentu yang ditetapkan oleh peneliti untuk dipelajari dan kemudian ditarik kesimpulan (Sugiyono, 2012). Populasi dalam penelitian ini adalah seluruh siswa SMP Nurul Islam Ngemplak Boyolali kelas VII dan VIII tahun ajaran 2019-2020 yang berjumlah 138 siswa, terdiri dari 74 siswa, dan 64 siswi.

Menurut Isac dan Michael (dalam Wiratna, 2014:67-68) jika populasi 138 atau mendekati 140, maka sampel bisa dambil 100 responden. Maka dalam penelitian ini penulis mengambil 100 responden, dengan menggunakan metode sampel secara acak atau Random Sampling.

Untuk memudahkan pemahaman persoalan yang sedang diteliti, diperlukan skema kerangka pemikiran yang dapat mempermudah dalam pemecahan masalah. Adapun skema kerangka pemikiran dalam penelitian ini adalah sebagai berikut:

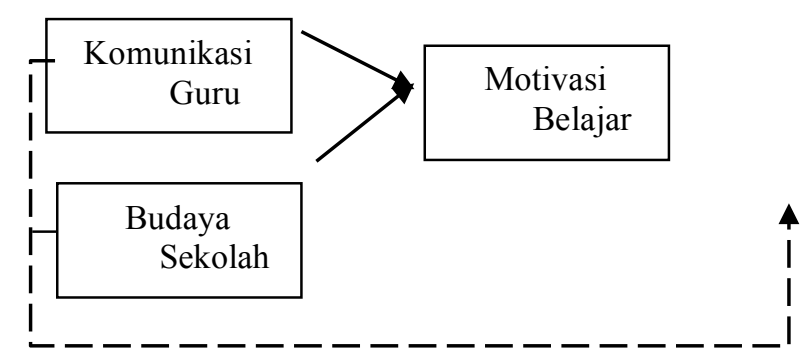

Gambar 1. Kerangaka Berpikir

Variabel-variabel dalam penelitian ini adalah komunikasi guru, budaya sekolah dan motivasi belajar. Komunikasi guru adalah penilaian terhadap kemampuan komunikasi antar pribadi guru dan siswa baik secara verbal maupun nonverbal yang 
diukur melalui indikator penilaian yaitu: komunikatif, kurang komunikatif, tidak komunikatif. Budaya Sekolah: Secara konseptual yang dimaksud dengan budaya sekolah adalah norma, nilai, kepercayaan, dan anggapan di anggotanya, yang berwujud simbol, artifak, ritual, seremoni, ideologi, dan bentuk perilaku. Adapun indikator budaya sekolah meliputi: 1) Perilaku rutin yang ada di sekolah untuk menanamkan nilai-nilai Islam; 2) Perilaku spontan yang menunjukkan kultur yang coba dibangun oleh sekolah; 3) Perilaku keteladanan secara praktik; 4) Pengkondisian dan pembangunan karakter; 5) Berbudaya kerja keras; 6) Budaya kerja sama; 7) Budaya saling menghormati dan menghargai. (Leithwood, dan Aitken, Jantzi, 2001:34)

Variabel Dependen dalam penelitian ini yaitu Motivasi Belajar Siswa. Adapun kisikisi instrumen penelitian dari motivasi belajar siswa adalah adanya hasrat dan keinginan berhasil, adanya dorongan dan kebutuhan dalam belajar, Adanya harapan untuk mencapai cita-cita masa depan, Adanya harapan untuk mendapat penghargaan, Adanya kegiatan yang menarik dalam belajar, Adanya usaha untuk mendapatkan kondisi belajar yang kondusif Hipotesis dalam penelitian ini adalah: diduga terdapat pengaruh komunikasi guru (X1) terhadap motivasi belajar siswa (Y) SMP Nurul Islam Ngemplak Boyolali. Diduga terdapat pengaruh budaya sekolah (X2) terhadap motivasi belajar siswa (Y) SMP Nurul Islam Ngemplak Boyolali. Diduga terdapat pengaruh secara simultan variabel komunikasi guru (X1) dan budaya sekolah (X2) terhadap motivasi belajar siswa (Y) SMP Nurul Islam Ngemplak Boyolali. Diduga variabel yang paling dominan mempengaruhi motivasi belajar siswa (Y) SMP Nurul Islam Ngemplak Boyolali adalah komunikasi guru (X1).

Uji Instrumen Validitas, Komunikasi Guru (X1). Komunikasi Guru (X1) dapat dinyatakan instrumen valid. Validitas Budaya Sekolah (X2). Uji
Validitas Budaya Sekolah (X2) dapat dinyatakan valid. Validitas Motivasi Belajar Siswa (Y). Uji Validitas Motivasi Belajar (Y) dapat dinyatakan valid. Uji reliabilitas untuk variable Komunikasi Guru (X1) diperoleh nilai Alpha Cronbach sebesar 0,763. Variabel Budaya Sekolah (X2) diperoleh Alpha Cronbach sebesar 0,763. dan untuk variabel Motivasi Belajar (Y) dapat diperoleh nilai Alpha Cronbach sebesar 0,761. karena masing-masing nilai Alpha Cronbach > 0.6, maka variabel dinyatakan reliabel

\section{Hasil dan Pembahasan}

Regresi Linier Berganda

Tabel 1

Regresi Linier Berganda

\begin{tabular}{|c|c|c|c|c|c|}
\hline \multirow[b]{2}{*}{ Model } & \multicolumn{2}{|c|}{$\begin{array}{l}\text { Unstandardized } \\
\text { Coefficients }\end{array}$} & \multirow{2}{*}{$\begin{array}{c}\begin{array}{c}\text { Standardized } \\
\text { Coefficients }\end{array} \\
\text { Beta }\end{array}$} & \multirow[b]{2}{*}{$\mathrm{t}$} & \multirow[b]{2}{*}{ Sig. } \\
\hline & B & Std. Error & & & \\
\hline 1 (Constant) & 27.448 & 6.808 & & 4.032 & .000 \\
\hline Komunikasi Guru & .395 & .054 & .482 & 7.326 & .000 \\
\hline Budaya Sekolah & .358 & .050 & .474 & 7.194 & .000 \\
\hline
\end{tabular}

Sumber: Data diolah 2020

Dari hasil tersebut maka dapat diperoleh persamaan regresinya: $\mathrm{Y}=27,448+0,395$ $\mathrm{X}_{1}+0,358 \mathrm{X}_{2}$.

Uji t

Tabel 2

Uji-t

\begin{tabular}{|c|c|c|c|c|c|}
\hline \multirow[b]{2}{*}{ Model } & \multicolumn{2}{|c|}{$\begin{array}{l}\text { Unstandardized } \\
\text { Coefficients }\end{array}$} & \multirow{2}{*}{$\begin{array}{c}\begin{array}{c}\text { Standardized } \\
\text { Coefficients }\end{array} \\
\text { Beta } \\
\end{array}$} & \multirow[b]{2}{*}{$\mathrm{t}$} & \multirow[b]{2}{*}{ Sig. } \\
\hline & B & Std. Error & & & \\
\hline 1 (Constant) & 27.448 & 6.808 & & 4.032 & .000 \\
\hline $\begin{array}{l}\text { Komunikasi } \\
\text { Guru }\end{array}$ & .395 & .054 & .482 & 7.326 & .000 \\
\hline $\begin{array}{l}\text { Budaya } \\
\text { Sekolah }\end{array}$ & .358 & .050 & .474 & 7.194 & .000 \\
\hline
\end{tabular}

Sumber: Data diolah 2020

Uji t yang berkaitan dengan Komunikasi Guru (X1) terhadap Motivasi Belajar (Y) Siswa SMP Nurul Islam Ngemplak Boyolali diperoleh hasil t hitung $=7,326>$ t tabel $=1,984$ maka Ho di tolak, berarti 
terdapat pengaruh antara Komunikasi Guru $\left(\mathrm{X}_{1}\right)$ terhadap Motivasi Belajar (Y) Siswa SMP Nurul Islam Ngemplak Boyolali.

Uji $t$ yang berkaitan dengan Budaya Sekolah (X2) terhadap Motivasi Belajar (Y) Siswa SMP Nurul Islam Ngemplak Boyolali diperoleh hasil t hitung $=7,194>$ t tabel $=1,984$ maka Ho di tolak, berarti terdapat pengaruh antara Budaya Sekolah $\left(\mathrm{X}_{2}\right)$ terhadap Motivasi Belajar (Y) Siswa SMP Nurul Islam Ngemplak Boyolali.

\section{Uji Bersama-sama (F)}

Tabel 3

Uji F

\begin{tabular}{|l|r|r|c|c|c|}
\hline Model & \multicolumn{1}{|c|}{$\begin{array}{c}\text { Sum of } \\
\text { Squares }\end{array}$} & df & $\begin{array}{c}\text { Mean } \\
\text { Square }\end{array}$ & F & Sig. \\
\hline 1 Regression & 20484.079 & 2 & 10242.040 & 104.128 & $.000^{\mathrm{a}}$ \\
Residual & 9540.961 & 97 & 98.360 & & \\
Total & 30025.040 & 99 & & & \\
\hline
\end{tabular}

Dari hasil perhitungan dengan menggunakan program komputer SPSS, maka maka diperoleh hasil $F$ hitung $104,128>\mathrm{F}$ tabel 2,70, artinya faktor independent yaitu Komunikasi Guru (X1) dan Budaya Sekolah (X2) secara bersamasama berpengaruh terhadap Motivasi Belajar (Y) Siswa SMP Nurul Islam Ngemplak Boyolali.

\section{Uji Koefisien Determinasi $\left(R^{2}\right)$}

Tabel 4

Uji Koefisien Determinasi $\left(\mathrm{R}^{2}\right)$

\begin{tabular}{|l|r|r|l|}
\hline & & & \multicolumn{2}{|l|}{$\begin{array}{l}\text { Adjusted R } \\
\text { Square }\end{array}$} \\
\hline 1 & $\mathrm{R}$ & \multicolumn{1}{|c|}{ R Square } & \multicolumn{1}{|c|}{.676} \\
\hline
\end{tabular}

Dengan mengunakan program SPSS, maka dapat diperoleh untuk $\mathrm{R}^{2}$ sebesar 0,676 atau $67,6 \%$, artinya bahwa secara bersama-sama terdapat pengaruh antara variabel independen yaitu Komunikasi Guru $\left(\mathrm{X}_{1}\right)$, Budaya Sekolah (X2) terhadap Motivasi
Belajar (Y) sebesar 67,6\%, sedangkan yang $32,4 \%$ dipengaruhi oleh faktor lain, yang tidak diteliti seperti Lingkungan sekolah, Fasilitas sekolah, kepemimpinan kepala sekolah daln lain sebagainya.

\section{Pembahasan}

Berdasarkan hasil perhitungan dengan program SPSS, dapat diperoleh hasil untuk analisis regresi linier berganda didapat persamaan regresi bahwa variabel Komunikasi Guru $\left(\mathrm{X}_{1}\right)$ dan Budaya Sekolah (X2) berpengaruh secara positif dan signifikan terhadap Motivasi Belajar (Y).

$$
\mathrm{Y}=27,448+0,395 \mathrm{X}_{1}+0,358 \mathrm{X}_{2}
$$

$\mathrm{a}=27,448$, ini berarti, apabila faktor Komunikasi Guru $\left(\mathrm{X}_{1}\right)$ dan Budaya Sekolah (X2) dianggap konstan, maka mengakibatkan Motivasi Belajar (Y) Siswa SMP Nurul Islam Ngemplak Boyolali meningkat sebesar 27,448.

b1 = 0,395, ini berarti, apabila faktor Komunikasi Guru (X1) bertambah 1 satuan dan variabel Budaya Sekolah (X2) dianggap konstan, maka akan dapat meningkatkan Motivasi Belajar (Y) Siswa SMP Nurul Islam Ngemplak Boyolali meningkat sebesar 0,395

b2 $=0,358$ ini berarti, apabila faktor Budaya Sekolah (X2) bertambah 1 satuan, dan variabel Komunikasi Guru $\left(\mathrm{X}_{1}\right)$ konstan, maka dapat meningkatkan Motivasi Belajar (Y) Siswa SMP Nurul Islam Ngemplak Boyolali sebesar 0,358

Uji secara parsial, analisis uji $t$ variabel Komunikasi Guru (X1) sebesar 7,326 > t tabel 1,984, maka Ho ditolak. Artinya terdapat pengaruh positif dan signifikan variabel Komunikasi Guru terhadap Motivasi Belajar (Y) Siswa SMP Nurul Islam Ngemplak Boyolali meningkat sebesar 27,448. Dari hasil tersebut dapat menjawab hipotesis yang pertama yaitu "Diduga terdapat pengaruh Komunikasi Guru (X1) terhadap Motivasi Belajar Siswa (Y) SMP Nurul Islam Ngemplak Boyolali” terbukti kebenarannya

Uji t diperoleh hasil untuk t hitung Budaya Sekolah (X2) sebesar 7,194 > t tabel 1,984, 
maka Ho ditolak. Artinya terdapat pengaruh positif dan signifikan variabel Budaya Sekolah terhadap Motivasi Belajar (Y) SMP Nurul Islam Ngemplak Boyolali. Dari hasil tersebut maka hipotesis yang kedua berbunyi "Diduga terdapat pengaruh Budaya Sekolah (X2) terhadap Motivasi Belajar Siswa (Y) SMP Nurul Islam Ngemplak Boyolali" terbukti kebenarannya.

Uji F diperoleh hasil $\mathrm{F}$ hitung 104,128 > F tabel 2,70, artinya faktor independent yaitu Komunikasi Guru (X1) dan Budaya Sekolah (X2) secara bersama-sama berpengaruh terhadap Motivasi Belajar (Y) Siswa SMP Nurul Islam Ngemplak Boyolali. Jadi hipotesis yang ketiga berbunyi "Diduga terdapat pengaruh secara simultan variabel Komunikasi Guru (X1) dan Budaya Sekolah (X2) terhadap Motivasi Belajar Siswa (Y) SMP Nurul Islam Ngemplak Boyolali" terbukti kebenarannya

Untuk uji Determinasi diperoleh hasil $\mathrm{R}^{2}$ sebesar 0,676 atau $67,6 \%$, artinya bahwa secara bersama-sama terdapat pengaruh antara variabel independen yaitu Komunikasi Guru $\left(\mathrm{X}_{1}\right)$, Budaya Sekolah (X2) terhadap Motivasi Belajar (Y) sebesar $67,6 \%$, sedangkan yang $32,4 \%$ dipengaruhi oleh faktor lain, yang tidak diteliti seperti Lingkungan sekolah, Fasilitas sekolah, kepemimpinan kepala sekolah daln lain sebagainya.

Hipotesis yang ke empat berbunyi "Diduga variabel yang paling dominan mempengaruhi Motivasi Belajar Siswa (Y) SMP Nurul Islam Ngemplak Boyolali adalah Komunikasi Guru (X1)" terbukti kebenarannya, karena nilai besarnya $\mathrm{b} 1=$ $0,395>\mathrm{b} 2=0,358$

\section{Kesimpulan}

Seluruh instrumen penelitian dinyatakan valid dan reliabel, untuk kuesioner Komunikasi Guru (X1) diperoleh nilai rata-rata sebesar $71,73 \%$, artinya Komunikasi Guru (X1) cukup tinggi. Untuk Budaya Sekolah (X2) diperoleh nilai ratarata $78,6 \%$. Hal ini cukup tinggi juga
Budaya Sekolah SMP Nurul Islam Ngemplak Boyolali. Untuk Motivasi Belajar (Y) diperoleh nilai rata-rata 73,3\%, artinya cukup tinggi Motivasi Belajar siswa SMP Nurul Islam Ngemplak Boyolali. Untuk pengaruh Komunikasi Guru (X1) terhadap Motivasi Belajar (Y) sebesar 7,326 > t tabel 1,984, maka Ho ditolak. Artinya terdapat pengaruh positif dan signifikan variabel Komunikasi Guru terhadap Motivasi Belajar (Y) Siswa SMP Nurul Islam Ngemplak Boyolali. Untuk pengaruh Budaya Sekolah (X2) terhadap Motivasi Belajar (Y) diperoleh t-hitung sebesar 7,194 > t tabel 1,984, maka Ho ditolak. Artinya terdapat pengaruh positif dan signifikan variabel Budaya Sekolah terhadap Motivasi Belajar (Y) SMP Nurul Islam Ngemplak Boyolali. Terdapat pengaruh secara bersama-sama Komunikasi Guru (X1) dan Budaya Sekolah (X2) terhadap Motivasi Belajar (Y), hal ini ditentukan dengan besarnya nilai $F$ hitung 104,128 $>$ F tabel 2,70. Yang paling dominan mempengaruhi Motivasi Belajar Siswa (Y) SMP Nurul Islam Ngemplak Boyolali adalah Komunikasi Guru (X1) karena nilai besarnya b1 $=0,395$ $>\mathrm{b} 2=0,358$.

\section{Daftar Pustaka}

A.M., Sardiman. (2014). Interaksi dan Motivasi Belajar-Mengajar. Jakarta: Rajawali Press.

Alfiandi, Rizki. (2014). Korelasi Antara Profesionalisme Guru PAI dengan Prestasi Belajar Siswa di SMP Dua Mei Ciputat. Skripsi/Tesis. Universitas Islam Negeri Syarif Hidayatullah Jakarta. Diakses dari: http://repository.uinjkt.ac.id/dspace/ bitstream/123456789/24779/3/RIZK I\%20ALFANDI-FITK.pdf

Alo Liliweri, M. (2013). Dasar-Dasar Komunikasi Antar Budaya. Yogyakarta: Pustaka Pelajar. 
Ansar dan Masaong. (2011). Manajemen Berbasis Sekolah. Gorontalo: Sentra Media.

Darsono, Max. (1984). Belajar dan Mengajar. Jakarta: PT. Gramedia

Effendy, Onong uchjana. (2006). Ilmu

Komunikasi; Teori dan Praktek.

Bandung: Penerbit Remaja Rosda Karya

Hamalik, Oemar. (2004). Proses Belajar Mengajar, Jakarta: Rineka Cipta.

Leithwood, dan Aitken, Jantzi (2001). Making Schools Smarter: A sistem for Monitoring School and District Progress. Readernr. 71624,

Muhaimin. (2010). Manajemen Pendidikan; Aplikasinya dalam Penyusunan Rencana Pengembangan Sekolah, Madrasah, Cet. I. Jakarta: Kencana Prenada Media Group.

Nurkholis. (2003) Manajemen Berbasis Sekolah, Jakarta: Grasindo..

Nurwulan, Dewi. (2015). Pengaruh Budaya Sekolah terhadap Prestasi Belajar Siswa Pada Mata Pelajaran PAI. Skrips/Tesis. Universitas Islam Negeri Syarif Hidayatullah Jakarta. Diakses dari: http://repository.uinjkt.ac.id/dspace/ handle/123456789/34357

Rahmawati, Evi. (2014). Pengaruh Lingkungan Sekolah Terhadap Motivasi Belajar Siswa di SMP Muhammadiyah 22 Pamulang. Skripsi/Tesis. Universitas Islam Negeri Syarif Hidayatullah Jakarta. Diakses dari: http://repository.uinjkt.ac.id/dspace/ bitstream/123456789/24412/4/EVI\% 20RAHMAWATI-FITK.pdf

Soyomukti, Nurani. (2010). Pengantar

Sosiologi. Yogyakarta: Ar-Ruzz Media.

Sudrajat, Ajat. (2011). Membangun Budaya Budaya Sekolah Berbasis Karakter Terpuji, dalam Jurnal FIS UNY, 5(2).

Sugiyono. (2012). Metode Penelitian Pendidikan Pendekatan Kuantitatif,
Kualitatif dan $R \& D, \quad$ Bandung: Alfabeta.

Suriansyah, Ahmad. (2014) Hubungan Budaya Sekolah, Komunikasi, Dan Komitmen Kerja Terhadap Kinerja Guru Sekolah Dasar Negeri. Jurnal Cakrawala Pendidikan, 33(3), 358367.

https://doi.org/10.21831/cp.v3i3.238 0

Suriasumantri, Jujun S. (2003). Filsafat Ilmu Sebuah Pengantar Populer, Jakarta: Pustaka Sinar Harapan.

UU RI No. 14 Th. 2005, UU Guru dan Dosen, Cet. I.

UU RI No. 20 Th. 2003, Sistem Pendidikan Nasional, Cet. I. 